This item was submitted to Loughborough's Research Repository by the author.

Items in Figshare are protected by copyright, with all rights reserved, unless otherwise indicated.

\title{
East, west, would home really be best? On dissatisfaction with offshore- outsourcing and firms' inclination to backsource
}

PLEASE CITE THE PUBLISHED VERSION

https://doi.org/10.1016/j.jbusres.2017.11.008

PUBLISHER

(C) Elsevier

VERSION

AM (Accepted Manuscript)

\section{PUBLISHER STATEMENT}

This work is made available according to the conditions of the Creative Commons Attribution-NonCommercialNoDerivatives 4.0 International (CC BY-NC-ND 4.0) licence. Full details of this licence are available at: https://creativecommons.org/licenses/by-nc-nd/4.0/

\section{LICENCE}

CC BY-NC-ND 4.0

\section{REPOSITORY RECORD}

Sidhu, Jatinder S., and Julia Kotlarsky. 2019. "East, West, Would Home Really Be Best? on Dissatisfaction with Offshore-outsourcing and Firms' Inclination to Backsource". figshare. https://hdl.handle.net/2134/28045. 


\title{
East, West, Would Home Really Be Best?
}

\section{On Dissatisfaction with Offshore-Outsourcing and Firms' Inclination to Backsource}

\begin{abstract}
With so many firms seemingly disenchanted with their experiences of offshore outsourcing one may well wonder why relatively few of these firms choose to 'backsource' - i.e., bring their offshored operations back in-house. Of all sourcing decisions that firms take, backsourcing is perhaps the least understood and least researched. In this article we draw on the behavioral theory of the firm (BTF) to propose a new model in which differences in firms' inclination to backsource are ascribed to the level of dissatisfaction at not having achieved offshoring aspirations. Building on BTF concepts of bounded rationality, problemistic search and satisficing decisions, the model suggests that how this dissatisfaction with offshoring affects a firm's inclination to backsource is dependent on managerial expectations regarding technical challenges of reintegrating activities, possible financial losses, and potential decline in quality following backsourcing, as well as on internal political support and financial slack for backsourcing. SEM analysis of data from U.S. and U.K. firms shows support for the model. The study highlights the importance of recognizing the role of managerial perceptions and biases and subgroup political relations in shaping firms’ backsourcing behaviors. We also discuss the study's contributions to research and practice.
\end{abstract}

Keywords: Backsourcing; behavioral theory; managerial expectations; organizational politics; sourcing decisions. 


\section{Introduction}

There is tremendous interest in academic and professional circles in understanding more about the drivers and outcomes of firms' sourcing decisions. To advance understanding, key questions that need attention are why, what, where, how, and when firms outsource (Dibbern, Chin, \& Heinzl, 2012; DiRomualdo \& Gurbaxani, 1998; Mudambi \& Venzin, 2010; Mudambi \& Tallman, 2010; Tanriverdi, Konana, \& Ge, 2007) ${ }^{1}$ and offshore (Aron \& Singh, 2005; Doh, Bunyaratavej, \& Hahn, 2009; Farrell, 2006; Musteen, 2016). When addressing such questions, scholars have often tended to use transaction-cost economics (TCE) and the resource-based view (RBV) as lenses to model firms' sourcing decisions as rational choices that capitalize on either the cost or resource advantages that offshoring provides (Aubert, Rivard, \& Patry, 1996; Lewin, Massini, \& Peeters, 2009; Mudambi \& Venzin, 2010; Vivek, Banwet, \& Shankar, 2008). Notably, despite an increasing trend to bring offshored operations back in-house (Bhagwatwar, Hackney, \& Desouza, 2011; Ejodame \& Oshri, 2017), there has so far been little scrutiny of firms' decisions to backsource. The handful of studies that have looked at the phenomenon indicate that backsourcing seems to follow disenchantment with offshoring because of a failure to realize anticipated improvements in performance (Veltri, Saunders, \& Kavan, 2008; Whitten \& Leidner, 2006).

Importantly, however, disenchantment with offshoring does not always lead to backsourcing, raising the intriguing question of why these disappointed firms differ in their inclination to backsource. In this article, we address the question by using the behavioral theory

\footnotetext{
${ }^{1}$ Most articles cited here focus on both outsourcing and offshoring decisions. In this article, we use the terms offshoring and offshored as shorthand for, respectively, offshore outsourcing and activities, functions, and processes that are outsourced offshore.
} 
of the firm (see Argote \& Greve, 2007; Desai, 2016; Gavetti, Greve, Levinthal, \& Ocasio, 2012; Tyler \& Caner, 2016) as lens. Rooted in the work of scholars from the Carnegie School (Cyert \& March, 1963), the behavioral theory of the firm (BTF) offers an account of the decision-making process in firms that is based on realistic assumptions about human cognition and relations. This account suggests that decision making in firms is guided by decision makers' bounded rationality and organizational politics. As discussed in more detail later on in the article, we draw on the core ideas of BTF to articulate a model in which variation in firms' inclination to backsource is ascribed to differences in decision makers' dissatisfaction with offshoring, and the problemistic search for a solution that dissatisfaction prompts. Furthermore, the model suggests that whether dissatisfaction with offshoring ultimately leads to backsourcing is likely to depend on decision-makers' expectations regarding the technical difficulty of reintegrating offshored work, financial losses, and decline in product quality. Moreover, whether dissatisfaction leads to backsourcing is also likely to depend on what political support for backsourcing there is within the firm, and whether there is financial slack to facilitate the re-aggregation of the firm's value chain.

Structural equation modeling of data from a cross-industry survey of firms located in the U.S. and the U.K. provides support for the theoretical model. Empirical results show that, while greater dissatisfaction with offshoring is indeed associated with a greater inclination to backsource, the relationship is conditional on managerial perceptions and the political climate in a firm. In particular, the greater the financial loss and the greater the decline in product quality that managers expect to result from discontinuing offshoring, the weaker the relationship between dissatisfaction with offshoring and the inclination to backsource. Surprisingly, though, 
managerial expectations about the technical difficulty of reintegration do not seem to moderate the effect of dissatisfaction with offshoring. As regards political climate, dissatisfaction with offshoring has a stronger effect on inclination to backsource when there is more political support in the firm for backsourcing. Quite interestingly, contrary to our theoretical model, we find that financial slack weakens the effect of dissatisfaction with offshoring on inclination to backsource. This result seems to suggest that, because greater financial slack provides more buffer, it discourages firms from switching from offshoring to backsourcing - rather than undertaking such a radical shift, firms seem to prefer the status quo, pinning their hopes on an offshoring strategy, despite their dissatisfaction with it.

This article speaks directly to the timely question in this Special Issue's call for papers, namely, “[w]hat are the factors that influence a firm’s decision to re-shore and back-source?” As the decision to backsource is a poorly understood aspect of firms' outsourcing and offshoring decision making, the article makes several contributions to the literature. It presents one of the first theoretical and empirical inquiries into differences in firms' inclination to backsource, providing insights into why so many firms are hesitant to backsource, in spite of the widespread dissatisfaction with offshoring reported in the news and business press. It adds to the literature by showing that the expectations of boundedly rational decision makers and organizational politics, both of which are variables that have not received sufficient attention in prior work, play a critical role in guiding backsourcing decisions. More generally, by employing the BTF lens the article augments the literature, complementing earlier research that used TCE and RBV frameworks to suggest that sourcing decisions are shaped by rational cost and resource considerations (cf. Lewin et al., 2009; Mudambi \& Venzin, 2010). Since backsourcing and 
outsourcing are essentially two sides of the sourcing coin, the article indicates that there may be value in also examining outsourcing using a BTF lens - outsourcing choices may very well reflect managerial biases and company politics. In this regard, the article provides a valuable addition to a growing stream of offshoring research that has started to draw on BTF to advance our understanding of sourcing decisions (Massini, Perm-Ajchariyawong, \& Lewin, 2010; Musteen, 2016). Overall, the article offers a behavioral explanation of why some firms may be more inclined than others to 'remake' rather than to 'continue to buy'.

\section{Research background}

\subsection{Sourcing decisions, and the incidence and challenges of backsourcing}

Outsourcing, offshoring, and backsourcing form a spectrum of sourcing options (Aron \& Singh, 2005; Dedrick, Carmel, \& Kraemer, 2011; Metters, 2008; Mudambi \& Venzin, 2010). Whereas outsourcing refers to the contracting of external service providers to carry out some of a client firm's value-chain functions, processes, and activities for a specified length of time and at an agreed cost and service level, offshoring (i.e., offshore outsourcing) refers specifically to the contracting of external service providers operating from an offshore location, usually a developing country separated from the client firm's country by an ocean (Oshri, Kotlarsky, \& Willcocks, 2015). Backsourcing, in contrast, is the practice of bringing offshored operations back in-house (Hirschheim \& Lacity, 1998; Whitten \& Leidner, 2006). The backsourcing process starts with a decision by a client firm to terminate its existing offshore contracts, and it culminates in the reintegration of the previously offshored operations into the firm's value chain $^{2}$.

\footnotetext{
2 As defined here, backsourcing can be distinguished from 'insourcing', which refers particularly to the termination of an outsourcing contract with a view to rebuilding the IT infrastructure internally (e.g., Hirschheim \& Lacity, 2000). Backsourcing
} 
The last decade has witnessed a growth in the phenomenon of backsourcing across industries. For example, in the retail sector, in 2006 Sainsbury backsourced its IT systems from Accenture in a deal worth over \$2 billion. In the banking sector, in 2011 the Spanish bank Santander brought back its contact centers from India to the UK, and in 2013 Maybank Singapore brought back its IT function in-house after ten years of a multi-million dollar contract with CSC Computer Services. In terms of sheer scale, the termination of a contract between JP Morgan and IB - centering on the outsourcing of data-centers, helpdesks, and data and voice networks - stands out for the $\$ 5$ billion sum of money involved (Bhagwatwar et al., 2011; Overby, 2005). These and other backsourcing cases (see, for example, Kotlarsky \& Bognar, 2012) seem to signal that firms may backsource even more frequently in the future as part of their overall sourcing strategy (Dibbern, Goles, Hirschheim, \& Jayatilaka, 2004). The most common explanation for this growing use of backsourcing is firms' disenchantment with offshoring as offshoring goals are not realized (e.g., Bhagwatwar et al., 2011; Veltri et al., 2008).

It is important to note that successful backsourcing of offshored operations is not an easy or straightforward process. It represents a major change in sourcing strategy, and can be anticipated to produce substantial technical and financial challenges of the kind that usually accompany large system re-integration projects (Volkoff, Strong, \& Elmes, 2005). It may also entail legal difficulties linked to the termination of contracts with service providers (Bhagwatwar et al., 2011). In relation to technical challenges, one significant potential difficulty is that a firm's

can also be distinguished from 'reshoring', which refers to the practice of bringing a function that has been outsourced offshore back to the home country or home continent, but not back in-house (e.g., Gray, Skowronski, Esenduran, \& Rungtusanatham, 2013; Musteen, 2016). 
capabilities to carry out offshored operations in-house may have atrophied; these thus may need re-building by committing sufficient time and monetary resources to allow the offshored operations to be reincorporated effectively into the firm's value chain (Bhagwatwar et al., 2011; Ejodame \& Oshri, 2017). Below, we draw on the insights of the BTF to submit that, alongside other factors, decision-makers' expectations regarding the technical difficulty of reintegrating offshored operations, financial losses, and decline in product quality if offshore contracts are terminated, will form a crucial element in determining how dissatisfaction with offshoring affects firms’ inclination to backsource.

\subsection{The behavioral theory of the firm (BTF) and firms' inclination to backsource}

Two salient premises of the BTF are that decision makers in firms have bounded rationality and that firms are political entities made up of coalitions who may have shared as well as conflicting interests and goals (Cyert \& March, 1963; Eisenhardt \& Zbaracki, 1992; Gaba \& Joseph, 2013; Gavetti et al., 2012). Based on these premises, BTF maintains that the decision-making process in firms tends not to conform to the postulates of rational models of decision making, in which managerial decisions are viewed to reflect the selection of the best solution after undertaking a cost-benefit analysis of all possible options. BTF suggests that, typically, managerial decisions are in fact "satisficing" solutions, which reflect the bounded rationality of those making the decisions and the need for compromise, given the varied interests and goals of different factions in a firm. According to BTF, a failure to achieve an aspirational level of performance triggers a problemistic (i.e., problem-driven) search for a satisfactory rather than optimal solution. As decision makers do not have complete knowledge of all the alternative solutions and their relative pay-offs, decision-makers' coarse-grained expectations of the consequences of choosing 
a solution readily visible to them play a key role in decision making. Furthermore, having political support for a solution is vital because implementing a mutually acceptable solution is essential to avoid conflict in the firm. In addition, BTF draws attention to the slack available to a firm, because greater slack enables the firm to absorb the costs and the risks attached to switching to an acceptable alternative.

The BTF thus identifies failure to achieve aspirations, problemistic search, managerial expectations, politics, and slack as key concepts that have a bearing on decision making in firms, and thus on organizational behavior and outcomes. We draw on these core BTF ideas to propose the model outlined in Figure 1, in which the level of dissatisfaction with offshoring due to a failure to achieve the expected level of performance, predicts firms' inclination to move to backsourcing as a satisfactory alternative. In keeping with the BTF, the model suggests that managerial expectations regarding the technical difficulty of reincorporating offshored operations into the firm's value chain, and potential financial loss and decline in product quality from discontinuing offshoring, will moderate the extent to which dissatisfaction with offshoring inclines firms to backsource. The model additionally holds that political backing for backsourcing and the amount of financial slack available for it will also moderate the effect of dissatisfaction with offshoring on a firm's inclination to backsource. We now expand on these relationships and present the study's formal hypotheses by weaving together BTF arguments and accounts of firms' actual offshoring and backsourcing decisions.

\section{Hypotheses}




\subsection{Dissatisfaction with offshoring and the inclination to backsource}

It is usually suggested that the offshoring of parts of a firm's value chain is motivated by the hope that this will lead to improvements in performance, either because of lower costs or because of higher-quality factor inputs such as expertise, knowledge, and skills that are to be obtained by contracting with offshore service providers (Carmel \& Tjia, 2005; Manning, Larsen, \& Bharati, 2015; Oshri et al., 2015; Varadarajan, 2009). There is ample evidence to suggest, however, that performance improvements vary greatly across firms that offshore (Mani, 2006; Lacity, Khan, \& Yan, 2016). Dibbern, Winkler, and Heinzl (2008, p. 334) note in this regard that, "while realized cost savings through offshore outsourcing may range between 20 and 50 percent, studies also show that in about 50 percent of the cases offshore projects fail to achieve cost savings or that costs actually increase.” If firms fail to achieve the level of performance they had hoped for, managers are likely to feel dissatisfied with offshoring. According to the BTF, because dissatisfaction with a course of action motivates managers to find a solution that would lead to better performance (e.g., Desai, 2016; Greve, 2008), decision makers’ behavioral response to dissatisfaction with offshoring is likely to be the initiation of a problemistic search for a satisfactory alternative. Since backsourcing is a very obvious and potentially viable alternative to offshoring (cf. Whitten et al., 2010; Whitten \& Leidner, 2006), as decision makers' dissatisfaction with offshoring increases, so to should the likelihood of a problemistic search for an alternative to it, and thus an offshoring-to-backsourcing switch in sourcing strategy. Conversely, if decision makers are satisfied with offshoring and feel no need to search for another strategy, one can expect less inclination to backsource. Formally:

H1: The greater the level of dissatisfaction with offshoring, the greater the firm's inclination to backsource. 


\subsection{The moderating effect of managerial expectations}

The BTF suggests that managerial expectations play a crucial role in shaping decisions. When there is dissatisfaction with offshoring, managerial beliefs about the technical difficulty of reintegrating offshored activities with home operations could be particularly influential for the decision regarding whether or not to backsource. Such beliefs may form around a range of technical issues. For example, decision makers may have different perceptions of the technical challenges of reintegration, and of the feasibility and work required to make in-house and external systems compatible. Similarly, decision makers may vary in their beliefs about their firm's ability to regain the expertise needed to carry out offshored activities in-house (Bhagwatwar et al., 2011; Ejodame \& Oshri, 2017). Such expertise may need to be reacquired, either because a firm has lost domain and functional knowledge over time as a result of an activity being offshored, or because attention in the firm has shifted from focusing on technical problem-solving to managing relationships with service providers (cf. Bhagwatwar et al., 2011; Cullen, Seddon, \& Willcocks, 2005). When there is no definitive knowledge of how far technical difficulties will in fact be resolved over time, decision making will depend on decision makers’ beliefs (Cyert \& March, 1963; Gavetti et al., 2012). The more strongly decision makers believe that reintegrating offshored activities poses considerable difficulties, the less likely they are to see backsourcing as a satisfactory solution, and thus the weaker the relationship will be between dissatisfaction with offshoring and inclination to backsource. Formally:

H2: The positive relationship between dissatisfaction with offshoring and inclination to backsource will be weaker when decision makers expect the technical difficulties in reintegrating offshored activities with in-house activities to be greater. 
One can also assume that managerial expectations concerning the financial and quality consequences of discontinuing offshoring will moderate the influence of dissatisfaction with offshoring on inclination to backsource. Backsourcing can involve financial loss in the form of non-capitalization of returns on monetary and psychological investments in offshoring relationships (Whitten et al., 2010). Moreover, firms could incur financial losses as a result of penalties and legal fees attached to terminating contracts. Bhagwatwar et al. (2011, p.166) report, for example, that, "JP Morgan paid IBM millions of dollars for terminating [their] outsourcing contract, which approximated to some $15 \%$ of the total cost. This approximated to JPMC spending somewhere between \$14 million and \$107 million in 2005 to bring its IT back in-house.” Similarly, Sainsbury’s incurred a substantial financial loss of U.S. \$65 million from terminating a contract early in order to bring its IT system and business processes back in-house (Bhagwatwar et al., 2011). As full information about financial losses from discontinuing offshoring is not available to decision makers who are considering backsourcing, decisions are likely to be based upon decision makers' rough beliefs about the potential level of financial loss (cf. Cyert \& March, 1963). In line with earlier research (Bromiley, 1991; Shinkle, 2012), we surmise that the greater the financial loss managers believe will ensue from discontinuing offshoring, the less likely they are to perceive backsourcing as a satisfactory solution, and thus the weaker the relationship will be between dissatisfaction with offshoring and inclination to backsource. Formally:

H3: The positive relationship between dissatisfaction with offshoring and inclination to backsource will be weaker when decision makers expect to incur a greater financial 
loss from discontinuing offshoring.

A relationship similar to the one posited above can also be anticipated with regard to the effect of managerial expectations about potential decline in product quality. That backsourcing can entail a decline in quality has been noted in the literature (e.g., Veltri et al., 2008). In illustration, let us consider the case of backsourcing data-center operations; if a firm does not possess state-of-the-art infrastructure and technical resources for using current platforms (e.g., Cloud-based services), it is likely to face serious challenges in ensuring continuity in the speed and scale of its service provision after it backsources operations. JP Morgan's experience of backsourcing its data-center and helpdesk operations indicates that, during the backsourcing process and even up to one year later, the service quality was severely affected, because the personnel transferred back from the service provider, IBM, were "not getting any work done [...] they did not want to commit to projects and they started slacking off” (Bhagwatwar et al., 2011, p.169). Importantly, uncertainty about the extent of any decline in quality levels after discontinuing offshoring means that sourcing decisions will be guided essentially by expectations of what that decline might be. These may be based on decision makers' assessments of whether the company still has the requisite knowledge to enable existing levels of quality to be maintained. Additionally, decision makers may take a certain view of how long it would take to rebuild quality levels (see also Ejodame \& Oshri, 2017). Consistent with the logic of our earlier hypotheses, the more decision makers expect quality to decline and believe that it will take longer to restore, the weaker the effect of dissatisfaction with offshoring will be on inclination to backsource. We postulate that:

H4: The positive relationship between dissatisfaction with offshoring and inclination 
to backsource will be weaker when decision makers expect discontinuing offshoring to lead to a larger decline in quality.

\subsection{The moderating effect of organizational politics}

As we noted above, the BTF draws attention to the significance of organizational politics in decision making. Since individuals and groups in firms may not always agree on means and ends, give and take are an integral part of the decision-making process in firms. The decision choices that emerge from this type of process are satisficing solutions for which there is broad approval in the firm (Cyert \& March, 1963; Eisenhardt \& Zbaracki, 1992). Consistent with this, several studies have noted that internal relations, the distribution of power, and politics all play a role in outsourcing decisions (Bidwell, 2012; Chakrabarty \& Whitten, 2011; Heiskanen, Newman, \& Eklin, 2008). Politics are also likely to matter when decision makers weigh up whether or not to switch from offshoring to backsourcing. Backsourcing can have serious implications for organizational structure and for work interdependencies - it can engender uncertainties and impact people’s tasks, workflows and workload, and also evaluation and rewards (Overby, 2005). As such, a decision to backsource may be met with considerable internal resistance. Indeed, it would seem that companies such as Cable \& Wireless, Sears, and Washington Mutual hired new people for key decision-making positions with a view to steering the firm towards a climate in which there was more openness to backsourcing (Veltri et al., 2008). In the light of the arguments above, we anticipate that a political climate which is favorable to bringing back offshored operations will temper the impact of dissatisfaction with offshoring on inclination to backsource. In particular, we expect the impact to be stronger when there is less internal 
resistance to backsourcing, and to be weaker when there is more resistance. Formally:

H5: The positive relationship between dissatisfaction with offshoring and inclination to backsource will be stronger when there is a more favorable political climate for backsourcing.

\subsection{The moderating effect of financial slack}

The notion of slack implies that there are more resources available to a firm than are strictly needed to carry out operations. BTF emphasizes that financial slack has an important influence on decision making in firms (Cyert \& March, 1963; Singh, 1986). Since it provides a buffer that allows the firm to absorb costs and take risks, it has been suggested to encourage the search for new solutions to problems (Salge, 2011; Iyer \& Miller, 2008). In line with this, we expect financial slack to strengthen the effect of dissatisfaction with offshoring on inclination to backsource. As financial slack increases, decision makers are likely to see backsourcing as a more feasible sourcing solution, because there is greater capacity to offset the numerous costs and expenses of backsourcing. For example, more financial slack should make it easier for a firm to meet the substantial costs of terminating offshored operations and bringing them back in-house (Overby, 2005). It should also allow the firm to absorb more easily the costs of searching for, acquiring and setting up physical assets for the backsourced activities, rehiring experts, training personnel, and meeting the additional workload on the support functions in a company, such as human resources, finance and accounting, and procurement. A study by Ejodame and Oshri (2017) illustrates this well, describing how a bank earmarked a significant amount of money to hire and train personnel in order to facilitate backsourcing. In view of this discussion, we predict that 
greater financial slack will strengthen the effect of dissatisfaction with offshoring on inclination to backsource. Formally:

H6: The positive relationship between dissatisfaction with offshoring and inclination to backsource will be stronger when more financial slack is available.

\section{Methods}

\subsection{Sample and data collection}

The sample for hypotheses testing was drawn from firms in the U.S. and the U.K. (the two largest markets worldwide in terms of spending on offshored operations). For the sake of generalizability, we targeted firms in varied business sectors, including financial services, distribution and logistics, and manufacturing. Using panel data on consumers of offshore services, we invited representatives from 36,038 firms in the U.S. and 13,804 firms in the U.K. to complete a web-based survey. In line with the "key informant" approach to data collection, the invited representatives were the firms' most senior executives (e.g., Goo, Huang, \& Hart, 2008). We used a set of screening questions to ensure that all of our respondents were executives who took offshoring and backsourcing decisions (i.e., in CEO, CIO, CTO or COO positions), had at least two years of offshoring experience with their current firm, and were in firms that paid at least US\$50,000 or more annually to offshore service provider(s). Of the 1192 representatives who accepted our invitation, 849 were screened out. We received usable, fully completed responses from 196 invitees, equating to a response rate of $16 \%$ among those who expressed interest in the survey. No evidence of non-response bias was found when comparing the industry affiliation of responding and non-responding firms. Further, a comparison of early and late respondents (i.e., those responding in the last three days of the one-week period for 
which the survey was open) did not reveal any significant difference with respect to any of the study's variables. Table 1 presents descriptive information about the sample.

\section{------PLACE TABLE 1 ABOUT HERE ------}

To avoid bias in the measurement of variables, we followed closely the guidelines suggested for web-based surveys (Dillman, 2000). To avoid bias that might arise because of confusion by respondents, all the questions and items were worded unambiguously, and response options were clearly explained and presented. Also, a “don’t know” response category was always included to avoid inaccurate responses, should a respondent not be able to answer a particular question or

item. Furthermore, with a view to encouraging truthful answers, respondents were assured of confidentiality and we underlined that the survey was linked to a scientific research project. Despite the steps we took, it is nevertheless possible that data from single informants may contain common-method bias. To verify that this was not the case, we employed Harman's onefactor test (Podsakoff \& Organ, 1986). As four factors having an eigenvalue of more than unity were necessary to account for the variance in the data, common-method bias did not seem to be a problem in our dataset.

\subsection{Measurement of variables}

The study's explanatory, moderating and dependent variables were measured using Likerttype items with seven-point response formats. All items were anchored at "strongly disagree" and "strongly agree” (see, for example, Nunnally \& Bernstein, 1994).

The study's explanatory variable, dissatisfaction with offshoring, was measured using three 
items: "Offshoring has been a disappointment for us", "The net benefits from offshoring have been minimal", and "We are satisfied with the performance levels of offshored activities" (reverse scored). Respondents were asked to keep in mind their firm's experience with offshoring in the last three years when rating the items. The Cronbach's reliability coefficient for the three-item instrument was 0.78 .

The five moderating variables were operationalized using single-item instruments. Specifically, we measured expected technical difficulties of reintegration with the item "We would experience significant technical difficulties in reintegrating offshored operations with inhouse activities". To measure expected financial loss, we used the item "We would suffer considerable financial loss if contracts with offshore service providers were terminated". To measure expected decline in quality, we used the item "Should we bring back offshored operations, we can expect substantial decline in our product quality”. To measure political climate favorable to backsourcing we used the item "The political climate in our company is unfavorable to bringing back offshored operations" (reverse scored). Lastly, to measure available financial slack, we used the item "We have enough financial slack to facilitate reintegration of offshored operations with in-house activities”.

To measure the study's dependent variable, inclination to backsource, we employed the following three items: "We are seriously considering bringing back offshored activities"; "We are firm in our commitment to offshoring" (reverse scored); and "We are thinking of sourcing more from our offshore service providers” (reverse scored). Respondents were asked to keep in mind their intentions regarding offshoring in the coming three years when rating the items. The 
Cronbach’s reliability coefficient for the three-item instrument was 0.76 .

In addition to the above, we included several control variables in our analysis that may potentially affect firms' inclination to backsource. To control for the effect of firms' home country on backsourcing, we included a dummy variable for firms located in the U.S.; firms in the U.K. served as the reference category. We similarly included dummy variables to control for industry effects on backsourcing. At the firm level, we controlled for firm size as indicated by firms' total assets. We also controlled for the global sales revenue of firms, and for firms' disbursements to offshore service providers. Moreover, based on respondents' “yes” or "no" answers to the question of whether their company had brought back any offshored activity during the last three years, we included a dummy variable to control for firms’ prior experience of backsourcing (Gefen, Wyss, \& Lichtenstein, 2008). Lastly, because decision-makers’ tenure may have a bearing on the inclination to backsource, we also controlled for the length of time respondents had been in their current position.

\section{Analysis and results}

We examined our data using SPSS Amos 22 software. We first did a confirmatory factor analysis (CFA) to estimate a measurement model of relationships between the study's constructs and the items used to measure the constructs; we then estimated a structural equation model of cause-effect linkages. With regard to the measurement model, we used maximum likelihood estimation to estimate parameters. The CFA results indicated a measurement model with a good fit $\left(\chi^{2}=44.30\right.$, d.f. $=28, \mathrm{p}=0.03$, CFI $=0.98, \mathrm{TLI}=0.96$, RMSEA $\left.=0.05\right)$. Furthermore, the composite reliability (CR) and the average variance extracted (AVE) for construct measures were above 0.80 and 0.50 respectively, values which can be taken to indicate convergent validity 
(Fornell \& Larcker, 1981). Additionally, we also examined the size and the significance of the factor loadings of measurement items. All factor loadings were above the recommended threshold of 0.50 (the lowest and the highest being 0.63 and 0.82 respectively) and all were statistically significant at the one percent level, indicating convergent validity, Furthermore, as the correlation coefficients for the construct measures were less than the square root of the AVE for the measures, the results also indicate discriminant validity. Taken together, the estimation results suggest that one can have confidence in the measurement properties of the instruments used to operationalize the study's constructs.

Table 2 shows the descriptive statistics and correlations between the study's variables. To estimate the structural equation model, we again used maximum likelihood estimation. The standardized values of the study's main and moderating variables were used to build interaction terms for hypotheses testing (Dawson, 2014). The results showed a structural model with an acceptable fit $\left(\chi^{2}=81.37\right.$, d.f. $\left.=49, \mathrm{p}=0.00, \mathrm{CFI}=0.97, \mathrm{TLI}=0.91, \mathrm{RMSEA}=0.06\right)$. Table 3 presents the parameter estimates, standard errors (S.E.), and significance levels. As shown in Table 4, several of the study's control variables had a statistically significant effect on inclination to backsource. In particular, bigger firms (in terms of assets) show a greater inclination to backsource offshored activities. On the other hand, firms with a larger sales revenue show less inclination to backsource. Also, prior experience of backsourcing has a negative effect on inclination to backsource, which might be due to the challenges and difficulties experienced previously when reintegrating offshored activities with in-house operations. Interestingly, decision-makers' length of tenure has a negative relationship with the inclination to backsource, implying that those who have been in post longer are more likely to continue to offshore. Most importantly, in support of Hypothesis 1, Table 4 also shows that 
dissatisfaction with offshoring has a strong positive effect on inclination to backsource $(\beta=0.57$, $\mathrm{p}<0.001)$.

------PLACE TABLE 2 AND TABLE 3 ABOUT HERE ------

As regards the hypothesized moderation effects, Table 3 indicates that, of the five interaction terms constructed to capture these effects, four are statistically significant. The significant linkages are shown visually in Figures $2-5$ to aid interpretation. Starting with the first moderation effect summarized in Hypothesis 2, there is no support for the idea that the expected level of technical reintegration difficulties will moderate negatively the effect of dissatisfaction with offshoring on inclination to backsource. It should be noted, though, that the variable does have a significant direct impact on inclination to backsource $(\beta=-0.25, \mathrm{p}<0.001)$. Further, in support of Hypothesis 3, expected financial loss moderates negatively the effect of offshoring dissatisfaction $(\beta=-0.19, \mathrm{p}<0.001)$; as captured in Figure 2 , there is less inclination to backsource when there is a higher expected financial loss. Further, there is also support for Hypothesis 4 . The relevant interaction term is negative $(-\beta=0.14, \mathrm{p}<0.05)$ and, as illustrated in Figure 3, with growing levels of offshoring dissatisfaction, there is less inclination to backsource when there are higher levels of expected service quality decline. Further, Hypothesis 5 is also supported - political climate has a significant moderation effect $(\beta=0.14, p<0.05)$. As seen in Figure 4, as dissatisfaction with offshoring increases, there is greater inclination to backsource if the political climate is more in favor of backsourcing. Surprisingly, there is no support for Hypothesis 6 - the negative interaction term $(\beta=-0.18, \mathrm{p}<0.05)$ in Table 3 and the plot in Figure 5 indicate that as dissatisfaction with offshoring increases, there is less inclination 
to backsource when there is more financial slack. We discuss this unexpected result in the next section.

\section{------PLACE FIGURES 2, 3, 4 AND 5 ABOUT HERE ------}

\section{Discussion}

While the backsourcing of offshored operations is on the rise, there has not yet been much research on firms' motivations for considering backsourcing, the factors that affect their tendency to backsource, and the consequences of backsourcing behavior. In this article, we draw on the behavioral theory of the firm (BTF) to explore in particular why firms that are alike in terms of their decisions to offshore some of their value-chain activities nevertheless differ in their inclination to backsource. Building on the core tenet of BTF that decision making in firms is guided by performance aspirations, problemistic search, managerial expectations, politics, and availability of slack, in this article we put forward a model which suggests that dissatisfaction with offshoring when performance aspirations are not met will fuel a firm's inclination to backsource. The model also suggests that the effect of dissatisfaction with offshoring on the inclination to backsource will be conditioned by managerial expectations regarding technical challenges, financial losses, and decline in quality following backsourcing, as well as by internal political support for backsourcing and the financial slack a firm has.

Analysis of data from firms located in diverse industries in the U.S. and U.K. provides support for the model. As theorized, unsatisfactory experience of offshoring appears to have a strong positive effect on firms' future inclination to backsource, a result wholly consistent with 
BTF's assertion that a failure to achieve performance aspirations triggers decision makers with bounded rationality to look for a satisfactory alternative strategy to improve performance (Cyert \& March, 1963; Tyler \& Caner, 2016). Interestingly, the result suggests the surge in backsourcing in recent years may reflect problem-driven search by managers rather than rational planning based on systematic evaluation of the long-term threats and opportunities associated with different sourcing alternatives - for example, investing more in current offshoring relationships, switching vendors, or moving to a new offshore location (cf. Bhagwatwar et al., 2011; Veltri et al., 2008). Furthermore, as we had theorized, managerial expectations seem to be an important moderator of the effect of dissatisfaction with offshoring on the inclination to backsource; this is in line with BTF's argument that limits to human rationality imply that decision-makers' determine their preferred solution to a problem based on their subjective perceptions of the environment, rather than on an objective cost-benefit analysis.

Interestingly, while the level of expected difficulty of reintegrating offshored operations with in-house operations was found to be inversely related to the inclination to backsource, it did not attenuate the positive relationship between offshoring dissatisfaction and the inclination to backsource. The negative direct effect is in keeping with what others have found in case study research, namely that technical reintegration is a major issue for firms who have decided to backsource (Bhagwatwar et al., 2011; Ejodame \& Oshri, 2017). As theorized, we found that higher levels of expected financial loss or decline in quality reduced the effect of dissatisfaction with offshoring on the inclination to backsource. Although these results underscore the significance of financial costs and quality issues in sourcing decisions, these results are new to the literature, which has typically linked outsourcing and offshoring decisions to actual cost and 
quality outcomes (cf. Veltri et al., 2008; Whitten \& Leidner, 2006). The present study indicates that, in line with the BTF (e.g., Gavetti et al., 2012), decision-makers' expectations about costs and changes in quality are also relevant factors in decisions concerning a switch in sourcing strategy from offshoring to backsourcing.

We also found that political backing for backsourcing strengthens the effect of dissatisfaction with offshoring on a firm's inclination to backsource. In the BTF, politics are deemed to be important in identifying a satisfactory solution, in that a course of action which enjoys broad support in a firm should keep conflict at bay (Cyert \& March, 1963; Gaba \& Joseph, 2013). In the traditional view of backsourcing, explanations for why firms do or do not backsource usually focus largely on the rational economic logic of costs and benefits; the effect of politics that we report brings to the literature a new element, which centers on subgroup processes and relationships. As organizational structure, resource allocation, distribution of power, and social relations more generally are likely to change when a firm backsources (e.g., Overby, 2005), politics is a significant factor in sourcing decisions that one cannot afford to overlook. Surprisingly, while our prediction was that financial slack would amplify the effect of dissatisfaction with offshoring by providing a buffer to facilitate backsourcing (Cyert \& March, 1963; Salge, 2011), we found the opposite. To explain, slack may engender a complacent mode of thinking, working against a sense of urgency to look for a different sourcing approach (cf. Desai, 2016). Relatedly, managers may believe that slack will allow them to resolve their dissatisfaction with offshoring by making additional investments - for example, by investing in the implementation of more controls (e.g., Kang, Wu, Hong, \& Park, 2012). 


\subsection{Contributions to the literature}

This article contributes to the literature on offshoring decision-making by addressing the crucial what and why questions that feature in this Special Issue's call for papers. With reference specifically to the what question, the article sheds light on the managerial and organizational factors that can influence a firm's decision to backsource. Here it expands the scope of past theoretical inquiry by going beyond earlier studies, which have typically used a TCE or RBV lens and laid emphasis on examining rational cost and quality considerations that are assumed to guide sourcing decisions (cf. Lewin et al., 2009; Vivek et al., 2008). By building on the behavioral theory of the firm, we throw new light on the importance for sourcing decisions of managers' expectations or beliefs about the likely pay-off of changing the firm's sourcing strategy. In doing so, we draw attention to an important issue connected to decision making that has not received much recognition in the outsourcing and offshoring literature, namely that managerial perceptions or biases can be influential in affecting firms’ sourcing decisions.

In addition to being, as this study shows, a relevant factor in decisions over whether to continue to offshore or to backsource, managerial biases are likely to be relevant more generally to the question of why firms choose to "make" or "buy" in the first place. This is because managers' expectations regarding the returns to be gained from these alternative sourcing strategies are likely to be determined, at least partly, by subjective elements such as their own

personality (e.g., optimism and sense of self-efficacy), experiences (e.g., past successes and failures), and values. The article also adds to the literature by throwing light on a second important factor likely to affect sourcing decisions. Just like other strategic decisions (see Desai, 2016; Gaba \& Joseph, 2013), sourcing decisions are not arrived at in a vacuum. Decision making 
and decision makers in companies are immersed in multi-level social and political relations and dynamics. This article highlights the fact that why firms choose one sourcing strategy over another can be a function of organizational politics. By contributing these insights, overall, the article expands our understanding of sourcing decisions, enriches the offshoring literature, and opens up new avenues for further inquiry and dialogue on backsourcing.

\subsection{Implications for practitioners}

At a practical level, for decision makers who have to choose whether to continue offshoring or to backsource, this study pinpoints the particular set of factors that need to be considered to reach a sound decision. Moving from offshoring to backsourcing implies a radical change in strategy, and implementing the strategy is likely to be a complex technical and social process with important economic consequences (see, for example, Kotlarsky \& Bognar, 2012). Those in charge would do well, therefore, to consider first whether dissatisfaction with offshoring can be addressed by, for example, resetting performance targets, renegotiating contracts, or through dispute resolution and relationship building (see, for example, Herath \& Kishore, 2009; Oshri et al., 2015). As regards the backsourcing option, decision makers could seek to supplement their gut feelings and perceptions about the potential consequences of backsourcing with more detailed assessments, in which they draw on all the information and expertise that can be marshaled by engaging with those who will be involved with or affected by backsourcing (cf. Veltri et al., 2008). A detailed feasibility study could, for example, provide greater clarity regarding the quality changes that might be expected and the time that will be needed to rebuild quality should it decline following backsourcing. In addition, the article points to the importance of managing internal politics. If intuition and data suggest that backsourcing is likely to be the 
better alternative, a more favorable climate for backsourcing should result if decision makers articulate a narrative and plan in which they anticipate the concerns of those who will be affected and demonstrate in a credible way how those concerns will be addressed. In this respect, decision makers need to think about how best to earmark the available financial slack to absorb the costs of backsourcing and alleviate concern.

\subsection{Limitations and suggestions for future research}

Although backsourcing by firms is receiving increased attention in academic circles and in the media, in the outsourcing and offshoring literature it is the least understood type of sourcing decision. One reason for this is that firms usually refrain from disclosing information about backsourcing to avoid jeopardizing relationships with suppliers and admitting that their offshoring decisions and investments have not been successful. Against this backdrop, while our research provides new insights into why firms that are dissatisfied with offshoring tend to differ in their inclination to backsource, the data we obtained from decision makers could not be supplemented with secondary data in order to provide a greater level of confidence in the study's results. Future research that can overcome this specific limitation would therefore be of great value.

Also, our study only examined firms' inclination to backsource. To build a fuller understanding, it would therefore be very useful for future work to examine also the actual backsourcing of activities. It is conceivable that firms dissatisfied with offshoring might attempt to deal with the situation by searching for and entering into contracts with new offshore service providers. This follows from our unexpected finding that firms with more financial slack are less 
inclined to backsource, despite their dissatisfaction with offshoring. Given the challenges that backsourcing entails, it is plausible that resource-rich firms may prefer to find new service providers rather than backsource. Future work that investigates this would improve our understanding.

In this study, we used data only from firms in the U.S. and in the U.K. While these two countries are the largest consumers of offshore outsourcing services in the world, other countries and regions are beginning to spend more on offshoring - a case in point are the Nordic countries in Europe. In light of this, it would be useful to study the backsourcing decisions of firms that are located in other countries/regions but that have accumulated significant offshoring experience. Clearly, much more research is needed to develop a better understanding of the backsourcing phenomenon, how it varies around the globe, and what factors allow firms to backsource successfully. We hope that this inquiry will stimulate many others. 


\section{References:}

Argote, L., \& Greve, H. R. (2007). A Behavioral Theory of the Firm - 40 Years and Counting: Introduction and Impact. Organization Science, 18(3), 337-349.

Aron, R., \& Singh, J. V. (2005). Getting Offshoring Right. Harvard Business Review, 83(12), 135-143.

Aubert, B. A., Rivard, S., \& Patry, M. (1996). A transaction cost approach to outsourcing behavior: Some empirical evidence. Information \& Management, 30(2), 51-64.

Bahli, B., \& Rivard, S. (2003). The information technology outsourcing risk: a transaction cost and agency theory-based perspective. Journal of Information Technology, 18(3), 211-221.

Bhagwatwar, A., Hackney, R., \& Desouza, K. C. (2011). Considerations for Information Systems "Backsourcing": A Framework for Knowledge Re-integration. Information Systems Management, 28(2), 165-173.

Bidwell, M. J. (2012). Politics and Firm Boundaries: How organizational structure, group interests, and resources affect outsourcing. Organization Science, 23(6), 1622-1642.

Blumenberg, S., Wagner, H. T., \& Beimborn, D. (2009). Knowledge transfer processes in IT outsourcing relationships and their impact on shared knowledge and outsourcing performance. International Journal of Information Management, 29(5), 342-352.

Bromiley, P. (1991). Testing a Causal Model of Corporate Risk Taking and Performance. Academy Management Journal, 34(1), 37-59.

Carmel, E., \& Tjia, P. (2005). Offshoring Information Technology. Sourcing and Outsourcing to a Global Workforce: Cambridge University Press.

Chakrabarty, S., \& Whitten, D. (2011). The Sidelining of Top IT Executives in the Governance of Outsourcing: Antecedents, power struggles, and consequences. IEEE Transactions on Engineering Management, 58(4), 799-814.

Chua, A. L., \& Pan, S. L. (2008). Knowledge transfer and organizational learning in IS offshore sourcing. Omega, 36(2), 267-281.

Cullen, S., Seddon, P., \& Willcocks, L. (2005). Managing Outsourcing: The Lifecycle Imperative. MIS Quarterly Executive 4(1), 229-246.

Cyert, R. M., \& March, J. G. (1963). A Behavioral Theory of the Firm. Englewood Cliffs, NJ: Prentice Hall.

Dawson, J. F. (2014). Moderation in management research: What, why, when, and how. Journal of Business and Psychology, 29(1), 1-19.

Dedrick, J., Carmel, E., \& Kraemer, K. L. (2011). A dynamic model of offshore software development. Journal of Information Technology, 26(1), 1-15.

Desai, V. M. (2016). The behavioral theory of the (governed) firm: Corporate board influences on organizations' responses to performance shortfalls. Academy of Management Journal, 59(3), 860-879. 
Dibbern, J., Chin, W., \& Heinzl, A. (2012). Systemic Determinants of the Information Systems Outsourcing Decision: A comparative study of German and United States firms. Journal of the Association for Information Systems, 13(6), 466-497.

Dibbern, J., Goles, T., Hirschheim, R., \& Jayatilaka, B. (2004). Information Systems Outsourcing: A Survey and Analysis of the Literature. DATA BASE, 35(4), 6-102.

Dibbern, J., Winkler, J., \& Heinzl, A. (2008). Explaining Variations in Client Extra Costs Between Software Projects Offshored to India. MIS Quarterly, 32(2), 333-366.

Dillman, D. A. (2000). Mail and internet surveys. New York: Wiley.

DiRomualdo, A., \& Gurbaxani, V. (1998). Strategic intent for IT outsourcing. Sloan Management Review, 39(4), 67-80.

Doh, J. P., Bunyaratavej, K., \& Hahn, E. (2009). Separable but not equal: the location determinants of discrete services offshoring activities. Journal of International Business Studies, 40(6), 926-943.

Eisenhardt, K. M., \& Zbaracki, M. J. (1992). Strategic Decision Making. Strategic Management Journal, 13(2), 17-37.

Ejodame, K., \& Oshri, I. (2017). Understanding Knowledge Re-integration in Backsourcing. Journal of Information Technology, 1-15, https://doi.org/10.1057/s41265-016-0007-5

Farrell, D. (2006). Smarter Offshoring. Harvard Business Review, (June 2006), 85-92.

Fornell, C. \& Larcker, D. F. (1981). Evaluating structural equation models with unobservable variables and measurement error. Journal of Marketing Research, 18(1), 39-50.

Gaba,V. \& Joseph, J. 2013. Corporate structure and performance feedback: Aspirations and adaptation in M-form firms. Organization Science, 24(4), 1102-1119.

Gavetti, G., Greve, H. R., Levinthal, D. A., \& Ocasio, W. (2012). The Behavioral Theory of the Firm: Assessment and Prospects. The Academy of Management Annals, 6(1), 1-40.

Gefen, D., Wyss, S., \& Lichtenstein, Y. (2008). Business familiarity as risk mitigation in software development outsourcing contracts. MIS Quarterly, 32(3), 531-551.

Goo, J., Huang, C. D., \& Hart, P. (2008). A Path to Successful IT Outsourcing: Interaction Between Service-Level Agreements and Commitment. Decision Sciences, 39(3), 469-506.

Gray, J. V., Skowronski, K., Esenduran, G., \& Rungtusanatham, J. M. M. (2013). The reshoring phenomenon: What supply chain academics ought to know and should do. Journal of Supply Chain Management, 49(2), 27-33.

Greve, H. R. (2008). A behavioral theory of firm gorwth: Sequential attention to size and performance goals. Academy of Management Journal, 51(3), 476-494.

Grover, V., Cheon, M. J., \& Teng, J. T. C. (1996). The Effect of Service Quality and Partnership on the Outsourcing of Information Systems Functions. Journal of Management Information Systems, 12(4), 89-116. 
Heiskanen, A., Newman, M., \& Eklin, M. (2008). Control, trust, power, and the dynamics of information system outsourcing relationships: A process study of contractual software development. The Journal of Strategic Information Systems, 17(4), 268-286.

Herath, T., \& Kishore, R. (2009). Offshore Outsourcing: Risks, Challenges, and Potential Solutions. Information Systems Management, 26(4), 312-326.

Hirschheim, R., \& Lacity, M. C. (2000). The Myths and Realities of Information Technology Insourcing. Communications of the ACM, 43(2), 99-107.

Hirschheim, R. A., \& Lacity, M. C. (1998). Reducing Information Systems Costs through Insourcing: Experiences from the Field. Paper presented at the 31st Annual Hawaii International Conference on System Sciences, Hawaii.

Iyer, D. N., \& Miller, K. D. (2008). Performance Feedback, Slack, and the Timing of Acquisitions. Academy of Management Journal, 51(4), 808-822.

Kang, M., Wu, X., Hong, P., \& Park, Y. (2012). Aligning organizational control practices with competitive outsourcing performance. Journal of Business Research, 65(8), 1195-1201.

Kotlarsky, J., \& Bognar, L. (2012). Understanding the process of backsourcing: two cases of process and product backsourcing in Europe. Journal of Information Technology Teaching Cases, 2(2), 79-86.

Kotlarsky, J., Scarbrough, H., \& Oshri, I. (2014). Coordinating expertise across knowledge boundaries in offshore-outsourcing projects: The role of codification. MIS Quarterly, 38(2), 607627.

Lacity, M. C., Khan, S. A., \& Yan, A. (2016). Review of the empirical business process sourcing literature: an update and future directions. Journal of Information Technology, 31(3), 269-328.

Leonardi, P. M., \& Bailey, D. E. (2008). Transformational Technologies and the Creation of New Work Practices: Making Implicit Knowledge Explicit in Task-Based Offshoring. MIS Quarterly, 32(2), 411-436.

Lewin, A. Y., Massini, S., \& Peeters, C. (2009). Why are companies offshoring innovation? The emerging global race for talent. Journal of International Business Studies, 40(6), 901-925.

Mani, D. (2006). Successful Business Process Outsourcing. Sloan Management Review, 47(2), 5-6.

Manning, S., Larsen, M. M., \& Bharati, P. (2015). Global delivery models: The role of talent, speed and time zones in the global outsourcing industry. Journal of International Business Studies, 46(7), 850-877.

Massini, S., Perm-Ajchariyawong, \& Lewin, A. Y. (2010). Role of corporate-wide offshoring strategy on offshoring drivers, risks, and performance. Industry and Innovation, 17(4), 337-371.

McLaughlin, D., \& Peppard, J. (2006). IT Backsourcing: From 'Make or Buy' to 'Bringing IT back in-house. Proceedings of European Conference of Information Systems. https://aisel.aisnet.org/ecis2006/117 
Metters, R. (2008). A typology of offshoring and outsourcing in electronically transmitted services. Journal of Operations Management, 26(2), 198-211.

Mudambi, R., \& Venzin, M. (2010). The strategic nexus of offshoring and outsourcing decisions. Journal of Management Studies, 47(8), 1510-1533.

Mudambi, S. M., \& Tallman, S. (2010). Make, buy or ally? Theoretical perspectives on knowledge process outsourcing through alliances. Journal of Management Studies, 47(8), 14341456.

Musteen, M. (2016). Behavioral factors in offshoring decisions: A qualitative analysis. Journal of Business Research, 69(9), 3439-3446.

Nunnally, J. C., \& Bernstein, I.H. (1994). Psychometric theory (3rd edition). New York: McGraw Hill.

Oshri, I., Kotlarsky, J., \& Willcocks, L. P. (2015). The Handbook of Global Outsourcing and Offshoring (3rd edition ). London: Macmillan.

Overby, S. (2005). Backsourcing pain. CIO Magazine, 18(22), 64-72.

Podsakoff, P. M., \& Organ, D. W. (1986). Self-reports in organizational research: Problems and prospects. Journal of Management, 12(4), 531-544.

Salge, T. O. (2011). A behavioral model of innovative search: Evidence from public hospital services. Journal of Public Administration Research \& Theory, 21(1), 181-210.

Shinkle, G. A. (2012). Organizational aspirations, reference points, and goals: building on the past and aiming for the future. Journal of Management, 38(1), 415-455.

Singh, J. V. (1986). Performance, Slack, and Risk Taking in Organizational Decision Making. Academy of Management Journal, 29(3), 562-585.

Tanriverdi, H., Konana, P., \& Ge, L. (2007). The choice of sourcing mechanisms for business processes. Information Systems Research, 18(3), 280-299.

Tyler, B. B. \& Caner, T. (2016). New product introductions below aspirations, slack and R\&D alliances: A behavioral perspective. Strategic Management Journal, 37(5), 896-910.

Varadarajan, R. (2009). Outsourcing: Think more expansively. Journal of Business Research, 62(11), 1165-1172.

Veltri, N. F., Saunders, C., \& Kavan, C. B. (2008). Information Systems Backsourcing: Correcting Problems and Responding to Opportunities. California Management Review, 51(1), 83-102.

Vivek, S. D., Banwet, D. K., \& Shankar, R. (2008). Analysis of interactions among core, transaction and relationship-specific investments: The case of offshoring. Journal of Operations Management, 26(2), 180-197. 
Volkoff, O., Strong, D. M., \& Elmes, M. B. (2005). Understanding Enterprise Systems-Enabled Integration. European Journal of Information Systems, 1(42), 110-120.

Whitten, D., Chakrabarty, S., \& Wakefield, R. (2010). The strategic choice to continue outsourcing, switch vendors, or backsource: Do switching costs matter? Information \& Management, 47(3), 167-175.

Whitten, D., \& Leidner, D. (2006). Bringing IT back: An analysis of the decision to backsource or switch vendors. Decision Sciences, 37(4), 605-621.

Willcocks, L. P., Oshri, I., \& Hindle, J. (2012). Best-of-Breed versus Bundled Services. In L. P. Willcocks \& M. C. Lacity (Eds.), Advanced Outsourcing Practice: Rethinking ITO, BPO and Cloud Services (pp. 121-142). UK: Palgrave Macmillan. 


\section{TABLES AND FIGURES}

TABLE 1.

Sample information

\begin{tabular}{|c|c|c|c|}
\hline Descriptor & & Frequency & Percentage \\
\hline \multirow[t]{2}{*}{ Country: } & U.S. & 99 & 51 \\
\hline & U.K. & 97 & 49 \\
\hline \multirow{3}{*}{ Total Assets } & Up to $\$ 50$ million & 37 & 18.8 \\
\hline & $\$ 50$ million to $\$ 150$ million & 73 & 37.2 \\
\hline & More than $\$ 150$ million & 86 & 44.8 \\
\hline \multirow{8}{*}{ Business Sector } & Commercial & 23 & 11.7 \\
\hline & Distribution \& logistics & 30 & 15.3 \\
\hline & Electronics & 22 & 11.2 \\
\hline & Energy & 15 & 7.6 \\
\hline & Financial services \& insurance & 39 & 19.8 \\
\hline & Manufacturing & 30 & 15.3 \\
\hline & Media \& telecommunications & 20 & 10.2 \\
\hline & Pharmaceutical & 17 & 8.6 \\
\hline \multirow{3}{*}{$\begin{array}{l}\text { Offshore-Outsourced } \\
\text { Activities } \\
\text { (not mutually } \\
\text { exclusive) }\end{array}$} & Business processes & 277 & \\
\hline & $\begin{array}{l}\text { (customer-related, engineering, finance \& accounting, } \\
\text { human resources, procurement, } R \& D \text { ) }\end{array}$ & & \\
\hline & $\begin{array}{l}\text { IT development \& maintenance } \\
\text { (application development, application maintenance, data } \\
\text { center, infrastructure) }\end{array}$ & 333 & \\
\hline
\end{tabular}




\section{TABLE 2.}

Descriptive statistics and correlations

\begin{tabular}{|c|c|c|c|c|c|c|c|c|c|c|c|c|c|c|c|}
\hline Variable & Mean & SD & 1 & 2 & 3 & 4 & 5 & 6 & 7 & 8 & 9 & 10 & 11 & 12 & 13 \\
\hline 1. Firm location & 0.51 & 0.50 & 1.00 & & & & & & & & & & & & \\
\hline 2. Firm size (assets) & 6.69 & 1.84 & -0.05 & 1.00 & & & & & & & & & & & \\
\hline 3. Firm global revenue & 6.37 & 2.35 & 0.01 & 0.79 & 1.00 & & & & & & & & & & \\
\hline 4. Offshored amount & 6.32 & 1.86 & 0.05 & 0.50 & 0.51 & 1.00 & & & & & & & & & \\
\hline 5. Backsourcing experience & 0.42 & 0.49 & -0.07 & -0.03 & -0.10 & -0.02 & 1.00 & & & & & & & & \\
\hline 6. Tenure length & 6.03 & 1.52 & 0.05 & 0.18 & 0.15 & 0.20 & -0.00 & 1.00 & & & & & & & \\
\hline 7. Dissatisfaction with offshoring & 3.33 & 1.12 & -0.23 & 0.14 & 0.07 & -0.09 & -0.01 & -0.14 & 1.00 & & & & & & \\
\hline 8. Expected reintegration difficulties & 4.38 & 1.42 & 0.23 & -0.11 & 0.06 & 0.04 & -0.18 & 0.05 & -0.48 & 1.00 & & & & & \\
\hline 9. Politics favorable to backsourcing & 3.38 & 1.35 & -0.24 & 0.05 & -0.01 & 0.02 & 0.18 & 0.02 & 0.23 & -0.41 & 1.00 & & & & \\
\hline 10. Available financial slack & 4.73 & 1.43 & 0.24 & 0.05 & 0.06 & -0.01 & -0.18 & -0.03 & -0.23 & 0.34 & -0.55 & 1.00 & & & \\
\hline 11. Expected financial loss & 3.73 & 1.53 & -0.18 & 0.03 & -0.05 & 0.02 & 0.26 & -0.13 & 0.36 & -0.35 & 0.34 & -0.43 & 1.00 & & \\
\hline 12. Expected decline in quality & 4.49 & 1.37 & 0.10 & -0.16 & -0.06 & 0.08 & -0.07 & 0.07 & -0.61 & 0.50 & -0.11 & 0.13 & -0.25 & 1.00 & \\
\hline 13. Inclination to backsource & 3.03 & 1.05 & -0.24 & 0.08 & -0.06 & -0.16 & -0.11 & -0.17 & 0.62 & -0.50 & 0.17 & -0.26 & 0.19 & -0.48 & 1.00 \\
\hline
\end{tabular}

$\mathrm{N}=196$; correlation coefficients above 0.14 in absolute value are significant at the $5 \%$ level and those above 0.18 in absolute value are significant at the $1 \%$ level. 


\section{TABLE 3.}

Structural equation model (SEM) results for inclination to backsource

Path

\section{Controls}

Firm location

Firm size (assets)

Firm global revenue

Offshored amount

Backsourcing experience

Tenure length

Dissatisfaction with offshoring (DISO) [H 1]

Expected technical difficulties of reintegration

Expected financial loss

Expected decline in quality

Politics favorable to backsourcing

Available financial slack

\section{Main effects}

Estimate S.E.

$\longrightarrow$ Inclination to backsource $\quad-0.16 \quad 0.11$

$\longrightarrow$ Inclination to backsource

$0.110 .05^{*}$

$\longrightarrow$ Inclination to backsource

$-0.10 \quad 0.04^{*}$

$\longrightarrow$ Inclination to backsource

$\begin{array}{ll}-0.03 & 0.03\end{array}$

$\longrightarrow$ Inclination to backsource

$-0.210 .11^{*}$

$\longrightarrow$ Inclination to backsource

$-0.10 \quad 0.04^{* *}$

$\longrightarrow$ Inclination to backsource

$0.57 \quad 0.08^{* * *}$

$\longrightarrow$ Inclination to backsource

$-0.25 \quad 0.07 * * *$

$\longrightarrow$ Inclination to backsource

$-0.23 \quad 0.06^{* * *}$

$\longrightarrow$ Inclination to backsource

$-0.02 \quad 0.07$

$\longrightarrow$ Inclination to backsource

$0.17 \quad 0.07 *$

$\longrightarrow$ Inclination to backsource

$-0.20 \quad 0.07^{*}$

Moderation effects

DISO * expected technical difficulties of reintegration [H 2]

DISO * expected financial loss [H 3]

DISO * expected decline in quality [H 4]

DISO * politics favorable to backsourcing [H 5]

DISO * available financial slack [H 6] $\longrightarrow$ Inclination to backsource

$\longrightarrow$ Inclination to backsource

$\longrightarrow$ Inclination to backsource

$\longrightarrow$ Inclination to backsource

$\longrightarrow$ Inclination to backsource
$-0.08 \quad 0.06$

$-0.190 .06^{* * *}$

-0.14 0.06*

$0.14 \quad 0.07 *$

$-0.18 \quad 0.07 *$

$\mathrm{N}=196 ; * \mathrm{p} \leq .05 ; * * \mathrm{p} \leq .01 ; * * * \mathrm{p} \leq .001$ 
FIGURE 1.

Conceptual model and hypotheses

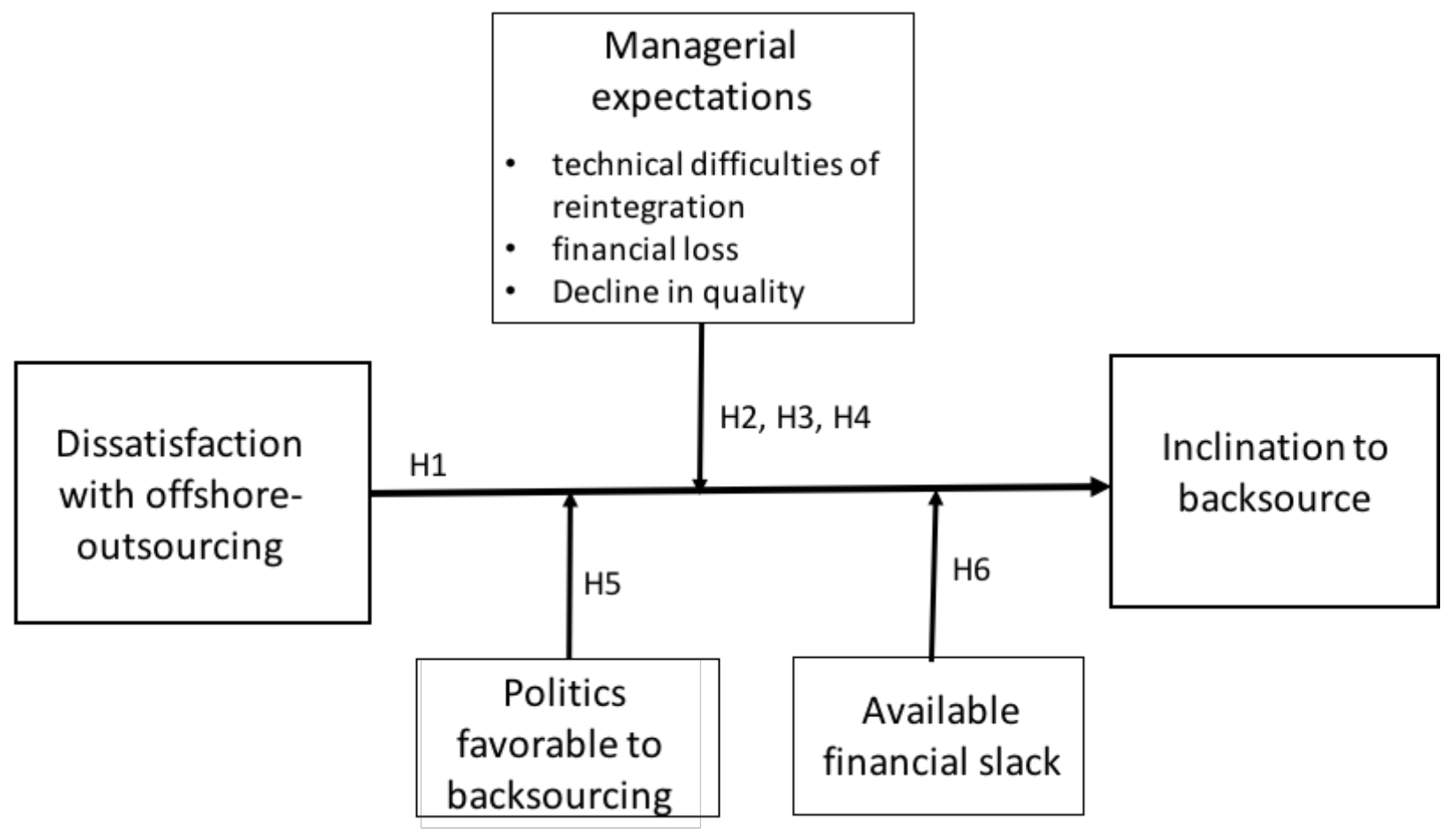


FIGURE 2.

Moderation effect of expected financial loss

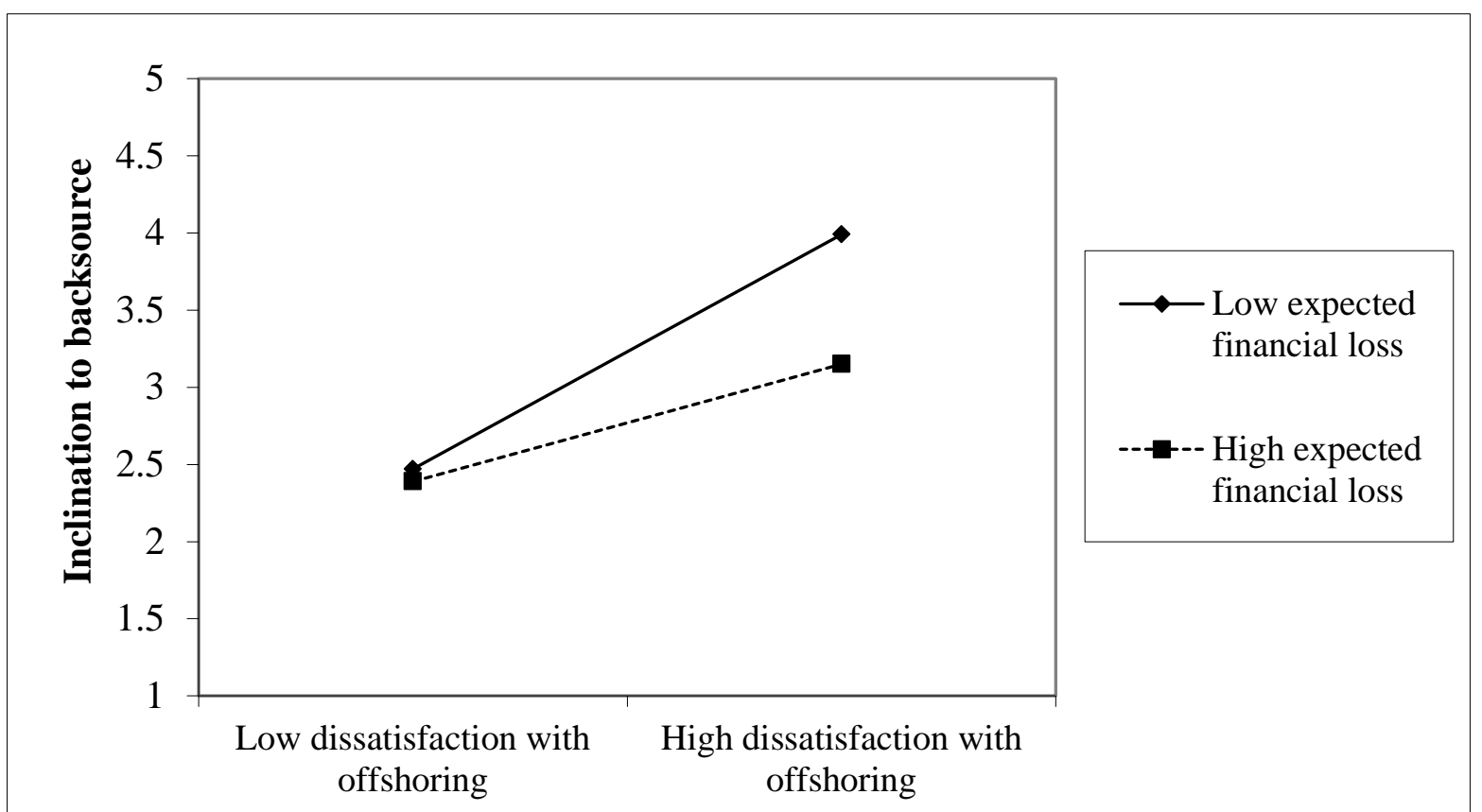

FIGURE 3.

Moderation effect of expected decline in quality

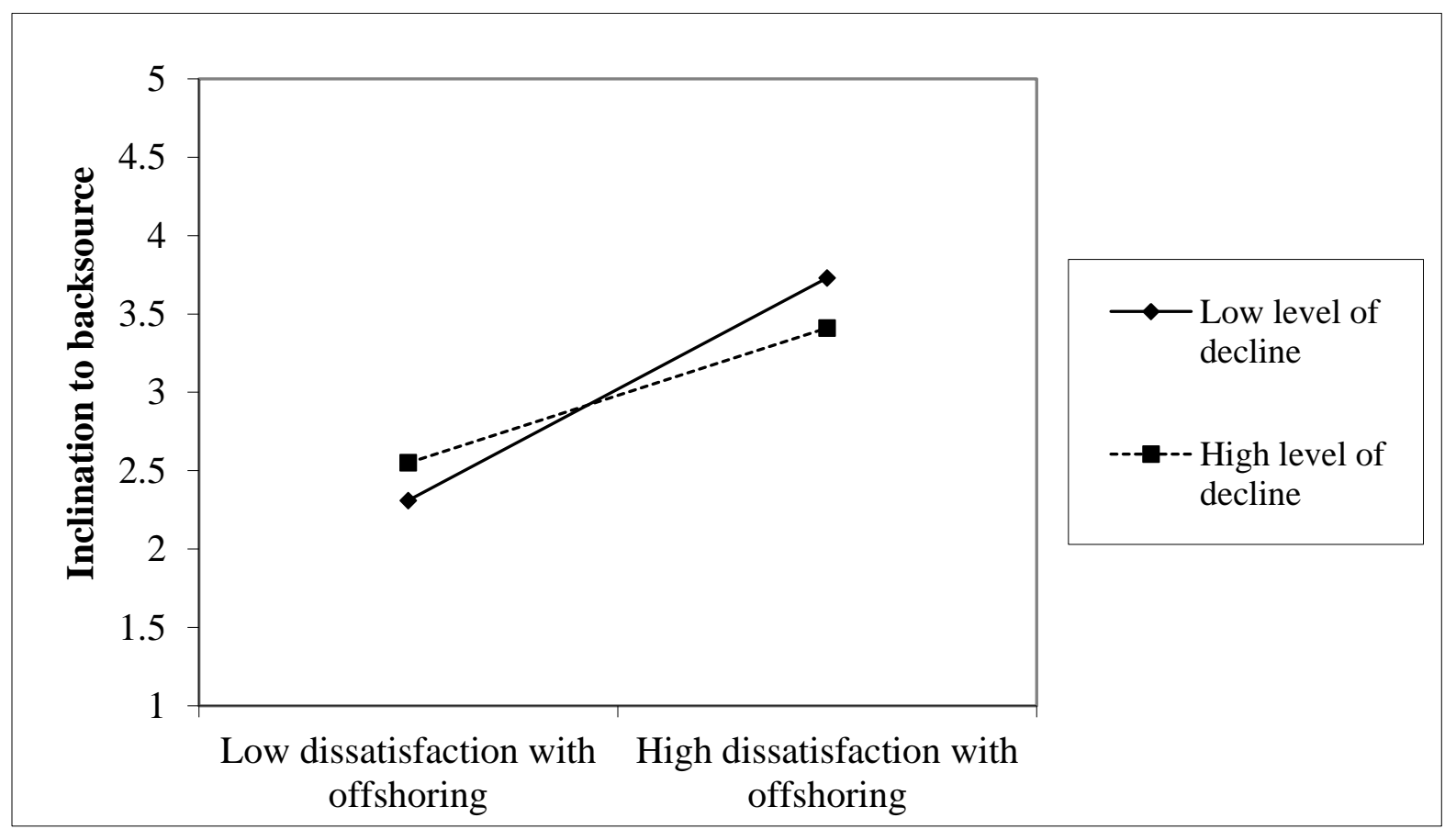


FIGURE 4.

Moderation effect of political climate favorable to backsourcing

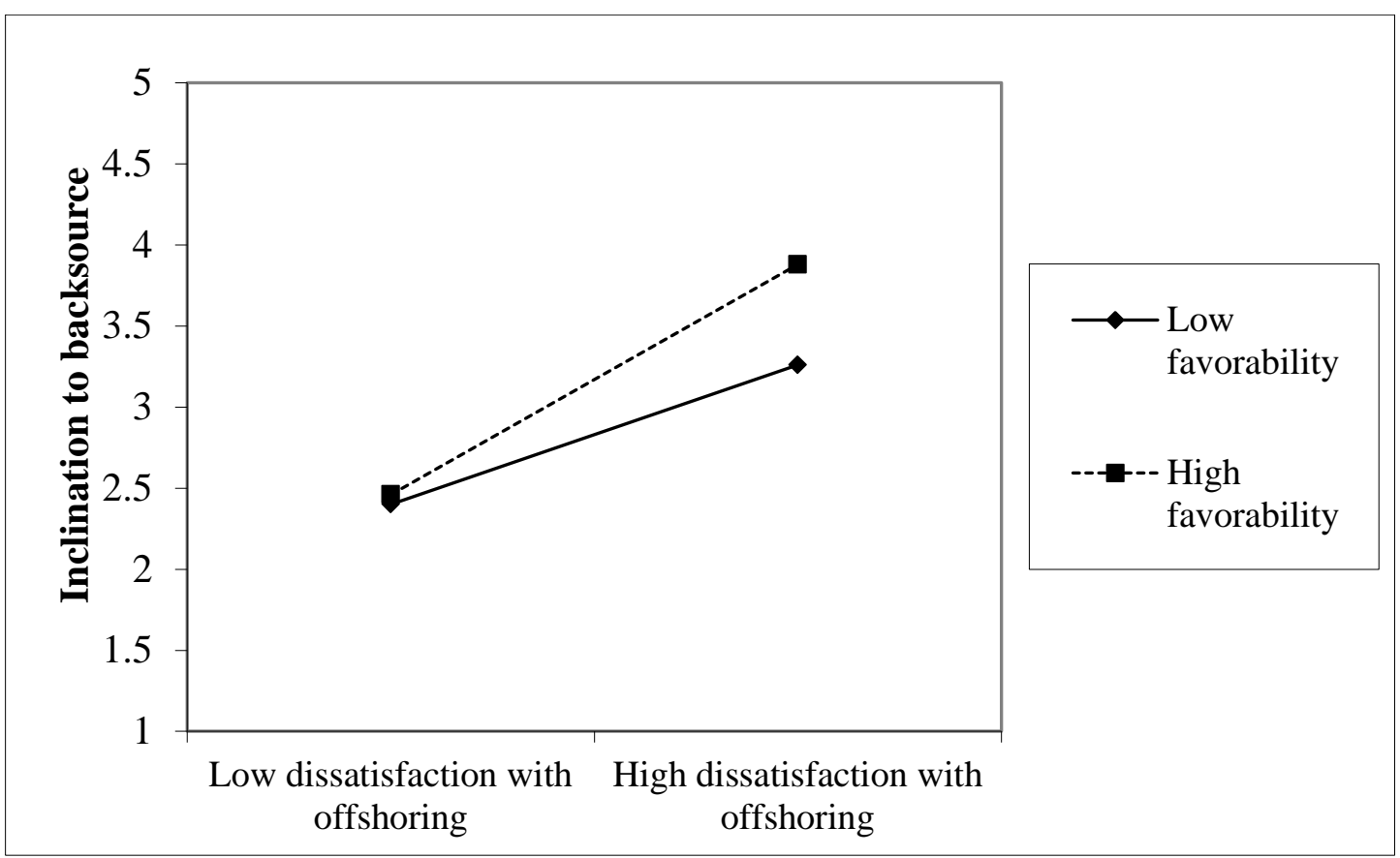

FIGURE 5.

Moderation effect of available financial slack

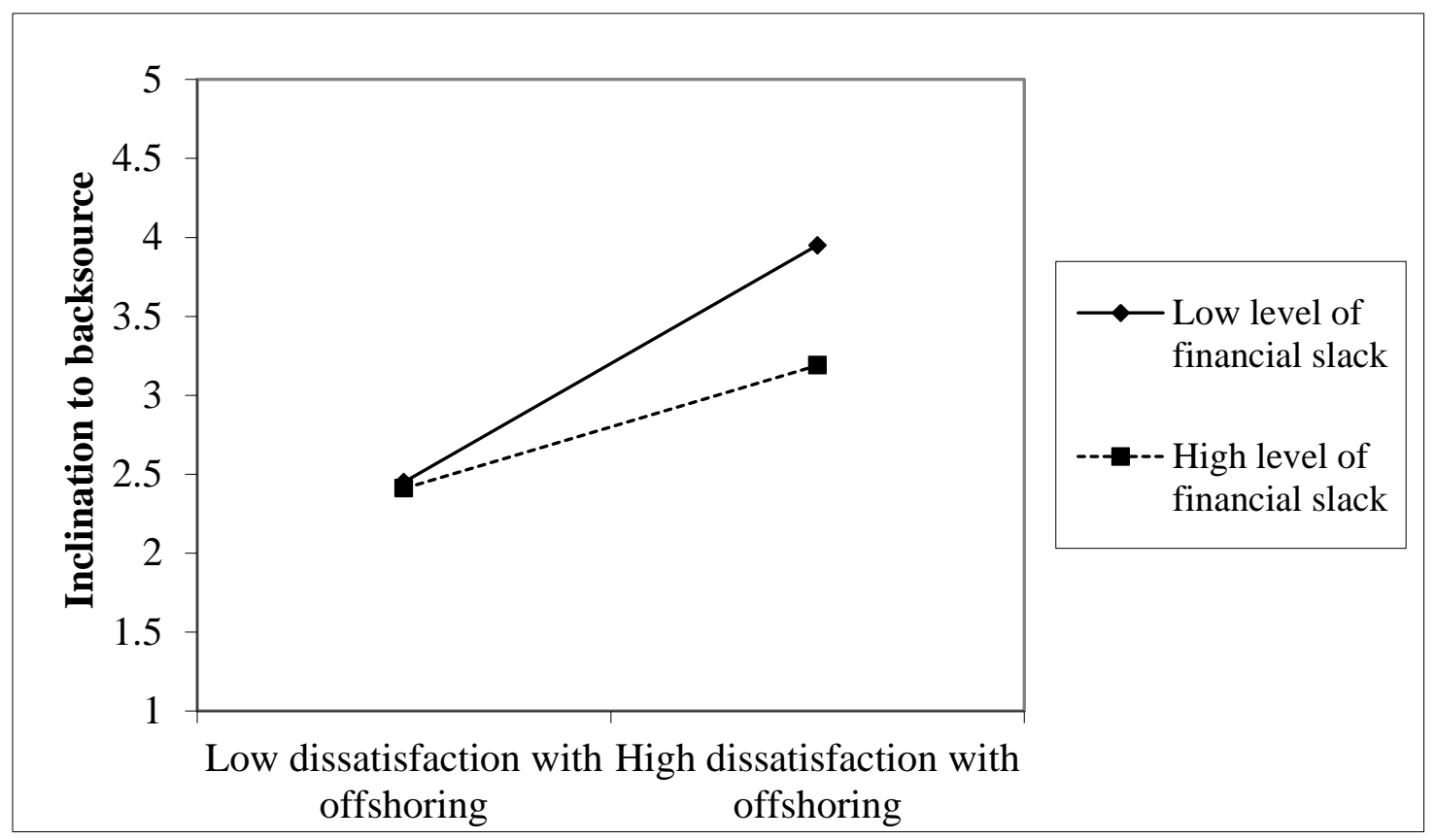

